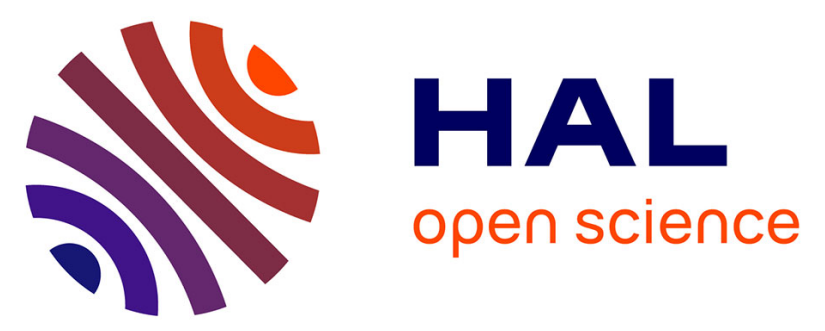

\title{
A new species of Linotetranus (Acariformes: Tetranychoidea: Linotetranidae) from the southeast of Iran
}

\author{
Mohammad Khanjani, E. Mohammadi, H. Izadi, Masoumeh Khnajani,
}

\section{- To cite this version:}

Mohammad Khanjani, E. Mohammadi, H. Izadi, Masoumeh Khnajani,. A new species of Linotetranus (Acariformes: Tetranychoidea: Linotetranidae) from the southeast of Iran. Acarologia, 2012, 52 (4), pp.419-424. 10.1051/acarologia/20122070 . hal-01567119

\author{
HAL Id: hal-01567119 \\ https://hal.science/hal-01567119
}

Submitted on 21 Jul 2017

HAL is a multi-disciplinary open access archive for the deposit and dissemination of scientific research documents, whether they are published or not. The documents may come from teaching and research institutions in France or abroad, or from public or private research centers.
L'archive ouverte pluridisciplinaire HAL, est destinée au dépôt et à la diffusion de documents scientifiques de niveau recherche, publiés ou non, émanant des établissements d'enseignement et de recherche français ou étrangers, des laboratoires publics ou privés.

\section{(1) (1) $\$$}

Distributed under a Creative Commons Attribution - NonCommercial - NoDerivatives| 4.0 


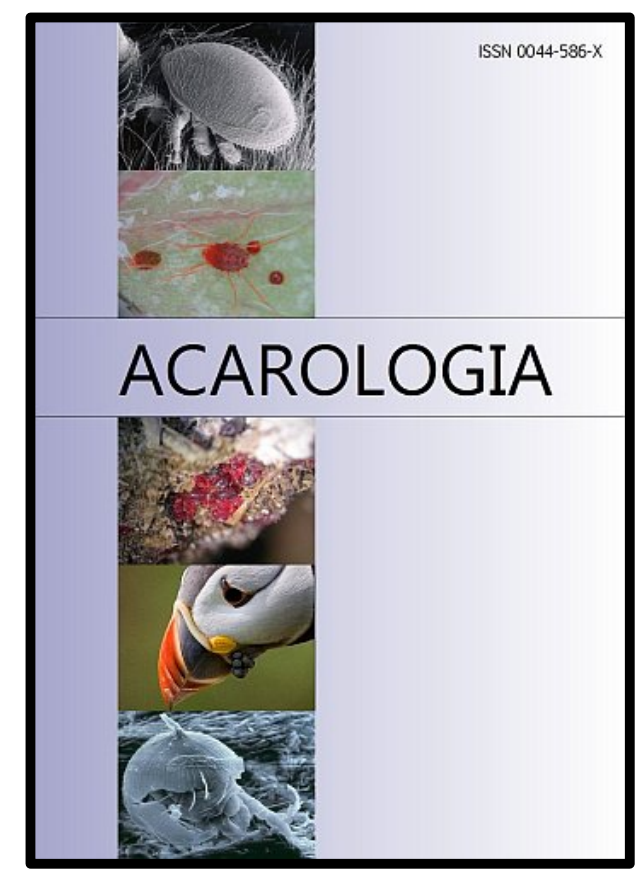

\section{ACAROLOGIA}

A quarterly journal of acarology, since 1959

Publishing on all aspects of the Acari

All information:

http://www1.montpellier.inra.fr/CBGP/acarologia/ acarologia@supagro.inra.fr

\section{OPEN ACCESS}

\section{Acarologia is proudly non-profit, with no page charges and free open access}

Please help us maintain this system by encouraging your institutes to subscribe to the print version of the journal and by sending us your high quality research on the Acari.

Subscriptions: Year 2017 (Volume 57): $380 €$ http://www1.montpellier.inra.fr/CBGP/acarologia/subscribe.php

Previous volumes (2010-2015): $250 € /$ year (4 issues)

Acarologia, CBGP, CS 30016, 34988 MONTFERRIER-sur-LEZ Cedex, France

The digitalization of Acarologia papers prior to 2000 was supported by Agropolis Fondation under the reference ID 1500-024 through the « Investissements d'avenir » programme

(Labex Agro: ANR-10-LABX-0001-01)
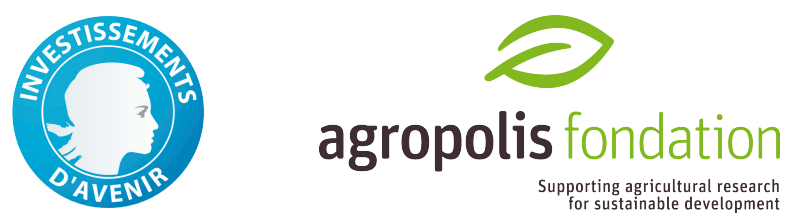

Acarologia is under free license and distributed under the terms of the

Creative Commons-BY-NC-ND which permits unrestricted non-commercial use, distribution, and reproduction in any medium, provided the original author and source are credited. 


\title{
A NEW SPECIES OF LINOTETRANUS (ACARIFORMES: TETRANYCHOIDEA: LINOTETRANIDAE) FROM THE SOUTHEAST OF IRAN
}

\author{
Mohammad KHANJANI ${ }^{1}$, Elham MOHAMMADI ${ }^{2}$, Hamzeh IZADI ${ }^{2}$ and \\ Masoumeh KHANJANI ${ }^{1}$
}

(Received 09 April 2012; accepted 25 July 2012; published online 21 December 2012)

${ }^{1}$ Department of Plant Protection, College of Agriculture, Bu Ali-Sina University, Hamedan, I. R. Iran. mkhanjani@gmail.com (corresponding author), mh.khanjani86@gmail.com

2 Department of Plant Protection, College of Agriculture, Vali-e-Aser University, Rafsanjan, Iran. elham.mohammadie@yahoo.com, izadi@mail.vru.ac.ir

\begin{abstract}
A new species Linotetranus eghbaliani $\mathbf{n} . \mathbf{s p}$. was collected from soil under apricot and almond trees, in the vicinity of Rafsanjan, Kerman province. A key to all known species of the world is provided.
\end{abstract}

KEYWORDS - mite; phytophagous; Tetranychoidea; soil; apricot; almond; Acari; Kerman

\section{INTRODUCTION}

The family Linotetranidae Baker and Pritchard, currently contains four genera namely: Afrolinotus Meyer and Ueckermann, Anoplopalpus Meyer and Ueckermann, Austrolinus Beard and Walter and Linotetranus Berlese (Khanjani et al., 2011). Linotetranid mites usually are colorless, slender and mostly inhabit soil (Bagheri et al. 2008). The genus Linotetranus was described by Berlese (1910) and to date has 12 species, namely: Linotetranus achrous Baker and Pritchard, 1953; L. ramosus Meyer and Ueckermann, 1997; L. protractulus Athias-Henriot, 1961; L. cylindricus Berlese, 1910; L. amiculus Meyer and Ueckermann, 1997; L. edenvillensis Meyer and Ueckermann, 1997; L. mirabebensis Andre, 1996; L. annae Meyer and Ueckermann, 1997; L. niknami Bagheri et al., 2008; L. anatolicus Doğan and Dönel, 2010; L. iraniensis Khanjani et al., 2011 and L. astra- galusi Khanjani et al., 2011. In this paper the thirteenth species is described from Iran.

\section{MATERIALS AND METHODS}

Mites were mounted directly on slides in Hoyer's medium (Krantz and Walter 2009). The slides were then dried in an oven $50^{\circ} \mathrm{C}$, sealed with nail polish and examined under a means of phase contrast Olympus BX51 microscope 400-1000X magnification. Drawings were made with a camera lucida. Body width was measured at the broadest point of idiosoma, just before coxa III or at the level of setae c4-c4. The terminology and setal notations follow that of Lindquist (1985).

All measurements are given in micrometers $(\mu \mathrm{m})$ and the measurements of paratype are given in brackets. Leg setal formulas are presented as the 
number of tactile setae followed by number of sensory setae in parentheses.

\section{FAMILY LINOTETRANIDAE BAKER AND PRITCHARD, 1953}

\section{Genus Linotetranus Berlese, 1910}

Type species: Linotetranus cylindricus Berlese, 1910

Diagnosis - Eyes absent; Prodorsum with four pairs of setae $\left(v_{1}, v_{2}, s c_{1}\right.$ and $\left.s c_{2}\right)$, opisthosomal dorsum with 17 or 18 pairs of setae $\left(d_{1}, e_{1}\right.$ and $f_{1}$ always present); palp five segmented, palptarsus with six phaners, palptibia with a claw and 1 or 2 setae, palpgenu with or without setae; palpfemur with 1 seta; coxa I with 2 setae, tibia II and IV with 4 setae, tarsus I with 2, tarsus II with 1 spindle-shaped solenidion distally, tarsi without forked setae.

\section{Linotetranus eghbaliani n. sp.} (Figs. 1-2)

Diagnosis - Setae $v_{1}$ bifurcate, palptarsus with one eupathidium and four simple setae, palptibia with two setae, palpgenu without setae; seate $e 4$ present, genital shields with three pairs of setae $\left(g_{1-3}\right)$.

Material examined - Two females, holotype female collected from soil beneath apricot trees, Prunus armeniaca (L.) (Rosaceae) and one paratype female collected from soil under almond trees, Amygdalus communis (L.) (Rosaceae), Rafsanjan (29 $58^{\prime} \mathrm{N}, 55^{\circ} 53^{\prime} \mathrm{E}$ and altitude $2600 \mathrm{~m}$ a.s.l), Kerman Province, Iran, 19, April 2010, Elham Mohammadi. The holotype female is deposited as slide-mounted specimens in the Collection of Acarology Laboratory, University of Bu-Ali Sina, Hamadan, Iran; one paratype female will be deposited in the mite collection of ARC-Plant Protection Research Institute, Pretoria, South Africa.

\section{Description}

Female $(\mathrm{n}=2)$ - Idiosoma elongate. Dimensions: Length of body (including gnathosoma) 432 (405) (excluding gnathosoma 351 (322); width 142 (145); length of leg I 147 (141); leg II 103 (102); leg III 93 (92); leg IV 93 (97).
Dorsum (Figure 1A) - Dorsal idiosoma reticulate and with 22 pairs of setae; all dorsal setae serrate; $v_{1}$ pinnate and bifurcate distally (Fig. 1B). Eyes absent. Caudal area anteriorely reticulate. Setae $f_{3}$ and $h_{2}$ is the longest seta on the dorsum. lengths of dorsal setae as follows (measurements of paratype in parentheses): $v_{1} 17$ (19), $v_{2} 39$ (38), sc 72 (79), $s c_{2}$ 75 (79); hysterosoma with 18 pairs of setae: $c_{1} 22$ (23), $c_{2} 48$ (50), $c_{3} 79$ (86), $c_{4} 89$ (94), d $d_{1} 25$ (24), d $d_{2} 57$ (50), $d_{3} 89$ (87), e e 13 (12), e 55 (60), e e 71 (72), e e 51 (47), $f_{1} 17$ (16), $f_{2} 34$ (32), $f_{3} 124$ (118), $h_{1} 45(41), h_{2}$ $132(142), h_{3} 64$ (63), $h_{4} 43$ (41);. Distances between setae: $v_{1}-v_{1} 4(5), v_{1}-v_{2} 28(29), v_{2}-v_{2} 39$ (39), $v_{2}-s c_{1} 36$ (37), $s c_{1}-s c_{1} 85$ (85), sc $s c_{1}-s c_{2} 24$ (24), $s c_{2}-s c_{2} 120$ (115), $c_{1}-c_{1} 61(60), c_{2}-c_{2} 95$ (99), $c_{1}-c_{2} 18$ (21), $c_{2}-c_{3} 16$ (16), $c_{3}-c_{3} 124$ (130), $c_{3}-c_{4} 31$ (35), $c_{4}-c_{4} 110$ (105), $d_{3}-d_{3} 94$ (88), $c_{1}-d_{1} 95$ (89), $d_{1}-d_{1} 15$ (16), $d_{1}-d_{2} 31$ (29), $d_{2}-d_{2}$ 73 (78), $d_{2}-d_{3} 12(10), d_{3}-d_{3} 94$ (88), $d_{3}-e_{3} 54$ (50), $e_{1}-d_{1}$

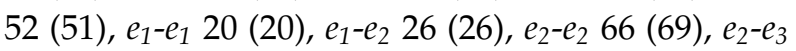
12 (10), $e_{3}-e_{3} 85$ (84), $e_{3}-e_{4} 12$ (13), $e_{4}-e_{4} 87$ (89), $e_{1}-f_{1}$ 39 (37), $f_{1}-f_{1} 31$ (34), $f_{1}-f_{2} 14$ (13), $f_{2}-f_{2} 54(55), f_{2}-f_{3} 5$ (6), $f_{3}-f_{3} 65$ (69), $f_{1}-h_{1} 28(30), h_{1}-h_{1} 15$ (13), $h_{1}-h_{2} 5$ (6), $h_{2}-h_{2} 24(24), h_{2}-h_{3} 4(4), h_{3}-h_{3} 29(37), h_{4}-h_{4} 44$ (43).

Venter (Figure 1C) - Ventral sculpturing reticulate-areolate. Area between setae $2 a$ and $3 a$ with transverse striae. Intercoxal area with four pairs of setae $(1 a, 2 a, 3 a, 4 a)$; setae $1 a$ two times longer than $3 a$ and $4 a ; 2 a$ serrate; two pairs aggential setae $\left(a g_{1-2}\right) ; a g_{1}$ on posterior part of aggenital shield, $a g_{2}$ situated on integument. Genital shields with three pairs of setae $\left(g_{1-3}\right), g_{2}$ longer than others; Pseudanal shields with three pairs of setae $\left(p s_{1-3}\right)$. Measurements of setae: $1 a 86$ (85), $1 b$ 23(24), 1c 13 (14), $2 a 63$ (68), $2 b 29$ (28), $3 a 45$ (40), 3b 22 (21), $4 a$ 43 (42), 4b 22 (21), $a g_{1} 37$ (32), $a g_{2} 16$ (20), $g_{1} 8$ (7), $g_{2}$ 14 (21), $g_{3} 7$ (9), $p s_{1} 11$ (12), , $p s_{2} 12$ (14), $p s_{3} 17$ (15). Distances between setae: 1a-1a 24 (24), 1a-2a 34 (35), 2a-2a 71 (74), 2a-3a 78 (61), 3a-3a 56 (55), 3a-4a 115 (116), 4a-4a 28 (25), ag $a g_{1} a g_{1} 30$ (29), ag $2-a g_{2} 68$ (64), $g_{1}-g_{1} 13$ (14), $g_{1}-g_{2} 10(9), g_{3}-g_{3} 20(21), g_{2}-g_{3} 9$ (9), $g_{2}-g_{2} 12$ (15), $p s_{1}-p s_{1} 21$ (21), $p s_{2}-p s_{2} 18$ (19), $p s_{3}-p s_{3}$ 15 (13), $p s_{1}-p s_{2} 6(7), p s_{3}-p s_{2} 8$ (8).

Gnathosoma (Figures 1D-F) - Palp five segmented; palp coxa longer than other segments. Palptarsus with four simple setae, one solenidion 3 (5) and one eupathidium 5 (5); tibia 8 (10) with two 


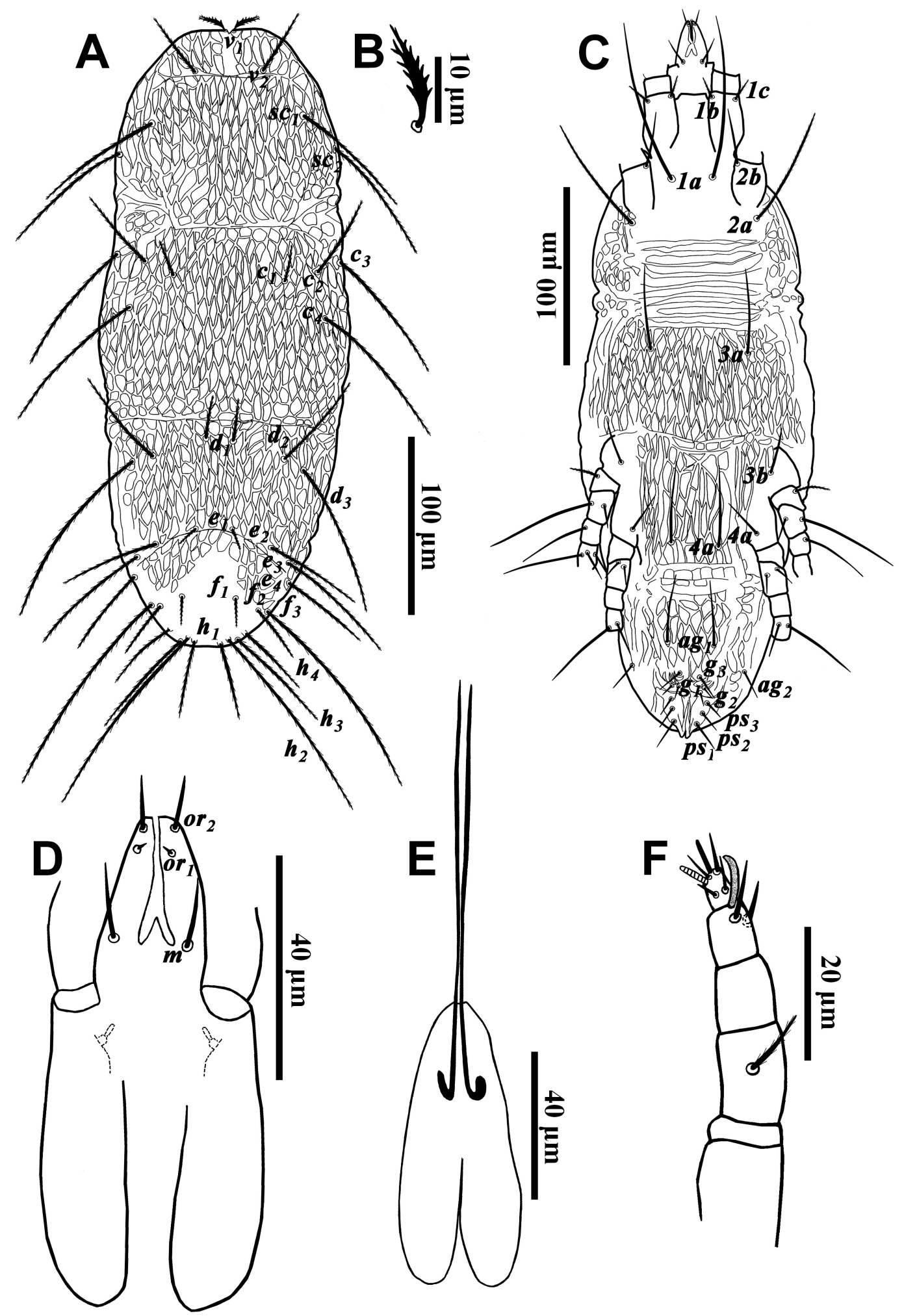

FIGURE 1: Linotetranus eghbaliani n. sp. (female): A - Dorsal view; B - prodorsal seta $v_{1}$; C - Ventral view; D - Ventral infracapitulum; E - Chelicera; F - Palp. 

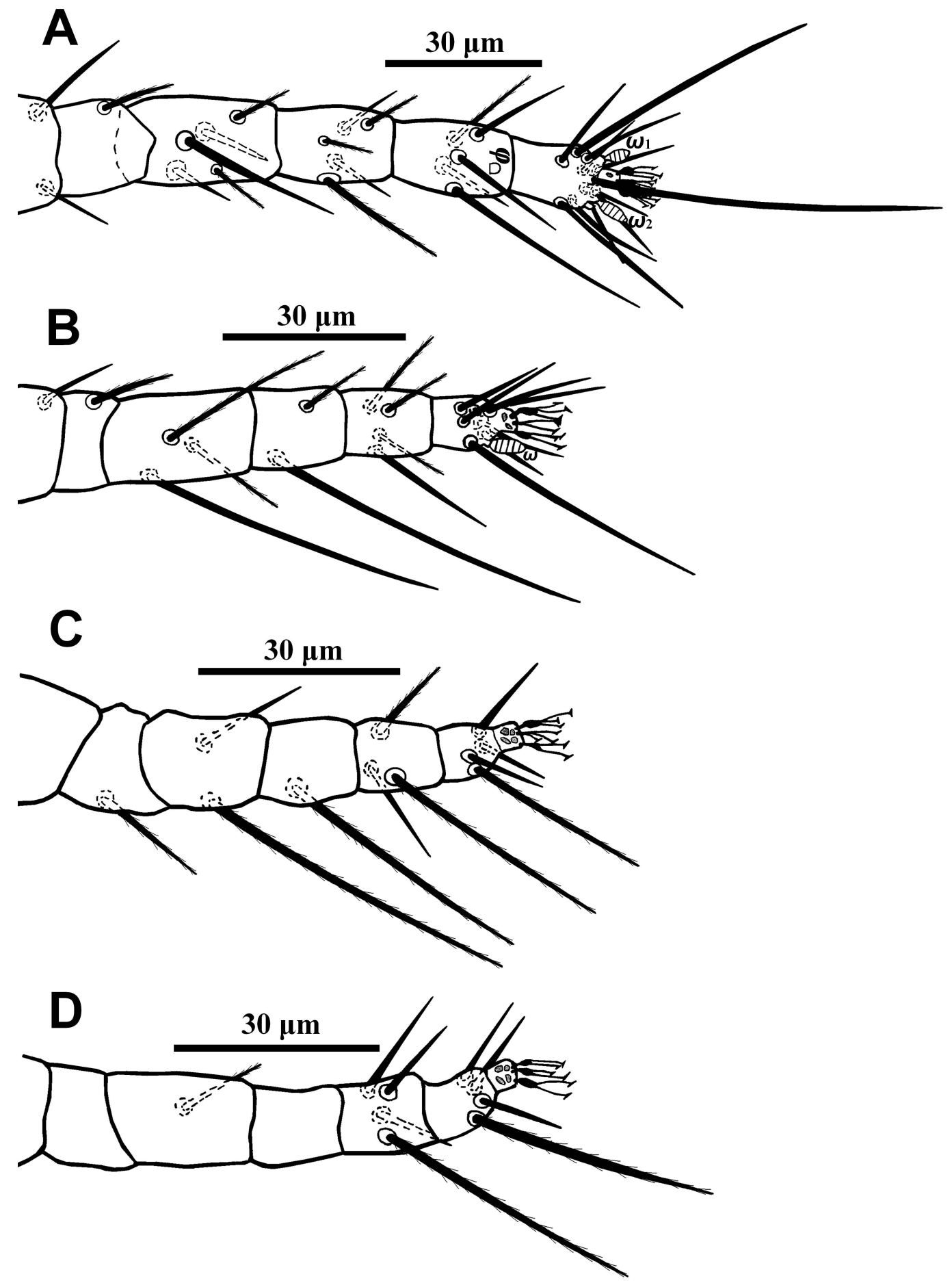

FIGURE 2: Linotetranus eghbaliani n. sp. (female): A - leg I; B - leg II; C - leg III; D - leg IV. 
setae and a dorsal claw; genua 10 (12) without setae; femora 12 (13) with one dorsal seta (Fig. 1F). Preoral setae or $_{1} 3$ (3), or 28 (10); hypostomal setae $m 14$ (18) (Fig. 1D). Length of chelicerae from the base to their tips 114 (121), stylophore as in figure 1E.

Legs (Figures 2A-D) - Setal formulae for legs IIV: coxae 2-1-1-1; trochanters 1-1-1-0; femora 5-3-21; genua 5-2-1-0; tibiae 5[1 $43(3)]-4-3-4$; tarsi $11(2 \omega)$ $7(1 \omega)-4-4$; solenidia on tarsus I-II and tibia I spindle shape $\mathrm{I} \omega 1$ 5(6), I $\omega 2$ 7(9), II $\omega$ 7(8).

Remarks - Linoterranus eghbaliani sp. nov. resembles L. anatolicus Doğan and Dönel, 2010 in having the same dorsal and ventral pattern and palpgenu without seta. However it differs from the latter by: setae $v_{1}$ bifurcate instead of simple in L. anatolicus, setae $h_{2}$ longest dorsal setae in the former but $f_{3}$ longest in the latter; palptarsus with one eupathidium versus four eupathidia in L. anatolicus and setae $e_{2} 55$ (56) oppose to $e_{2} 33$ (27-35).

Also the new species closely resembles Linotetranus astragalusi Khanjani et al., 2011 from Iran, in having the same leg setal formula, dorsal pattern and palpgenu without setae; however it differs from L. astragalusi by: area between $1 a$ - $2 a$ with transverse striae (rectangular reticulations in L. astragalusi); caudal area anteriorly reticulate (smooth in L. astragalusi), setae $v_{1}$ bifurcate (simple in L. astragalusi) and there are some dorsal setal length differences: $d_{2} 57$ (50) vs. 28 (27) in L. astragalusi; $e_{2} 29$ (27) vs. 55 (56) in L. astragalusi, $e_{4} 51$ (47) vs. 28 (29) in L. astragalusi.

Male and immature stages - Unknown

Etymology - This species is named in honor of Dr. Amir Hosein Eghbalian, close friend of senior author at the department of Plant Protection, College of Agriculture, Bu-Ali Sina University, Hamedan, Iran.

\section{Key to the world species of Linotetranus Berlese based on adult females (modified from Beard and Walter (2004) and Khanjani et al., 2011)}

1. Posterior dorsal opisthosomal setae $e_{4}$ absent........... L. achrous Baker and Pritchard, 1953 - Posterior dorsal opisthosomal setae $e_{4}$ present................................. 2

2. With 2 pairs of genital setae $\left(g_{1-2}\right) \ldots \ldots \ldots \ldots \ldots$ . L. ramosus Meyer and Ueckermann, 1997 — With 3 pairs of genital setae $\left(g_{1-3}\right) \ldots \ldots \ldots \ldots . . .3$

3. Posterior dorsal opisthosoma with transverse striae ......... L. protractulus Athias-Henriot, 1961 - Posterior dorsal opisthosoma smooth or with irregular striae.............................4

4. Palp tibia with 1 seta.................... 5

— Palp tibia with 2 setae .................. 6

5. Palp genu with 1 seta

L. cylindricus Berlese, 1910

- Palp genu without setae.

........ L. amiculus Meyer and Ueckermann, 1997

6. Genu I with 4 setae.

...... L. edenvillensis Meyer and Ueckermann, 1997

— Genu I with 5 setae...................... 7

7. Dorsal setae $d 3$ shorter than distance between d3-e3 ................ Lirabebensis André, 1996 - Dorsal setae $d 3$ longer than distance between $d 3$ -

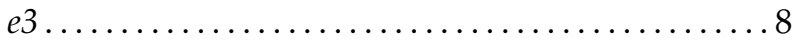

8. Palp genu without setae $\ldots \ldots \ldots \ldots \ldots \ldots 9$

— Palp genu with 1 seta .................. 12

9. Setae $f_{3}$ are the longest dorsal setae; ventral setae $3 a$ about as long as distance $3 a-3 a$.

L. annae Meyer and Ueckermann, 1997

- Setae $h_{2}$ or $h_{3}$ are the longest dorsal setae; ventral setae $3 a$ shorter than distance $3 a-3 a \ldots \ldots \ldots \ldots 10$

10. Setae $h_{2}$ the longest dorsal setae; palp tarsus with 1 eupathidium ........................11 - Setae $h_{3}$ the longest dorsal setae; palp tarsus with 4 eupathidia.... L. anatolicus Doğan and Dönel, 2010

11. Setae $e_{2} 55$ (56), setae $v_{1}$ bifurcate.......................... L. eghbaliani n. sp. 
- Setae $e_{2} 29$ (27), setae $v_{1}$ simple.

.................. L. astragalusi Khanjani et al., 2011

12. Palp tarsus with 4 eupathidia, $e_{2} 63-66$ (54) setae $h_{3}<h_{1} \ldots \ldots \ldots$.. niknami Bagheri et al., 2008 - Palp tarsus with 1 eupathidium; $e_{2} 95$ - 116 (104); setae $h_{3}$ subequal $h_{1}$

L. iraniensis Khanjani et al., 2011

\section{ACKNOWLEDGEMENTS}

This paper is a part of MSc thesis which was supported by University of Vali-e-Asr Rafsanjan, Iran. The authors wish to thank vice research of the president University for financial support of this project.

\section{REFERENCES}

Andre H.M. 1996 - Two new mites of the rare families Barbutiidae and Linotetranidae (Acari), from the Namib Desert - Acarologia, 36: 97-106.

Athias-Henriot C. 1961 - Nouveaux acariens phytophages d'Algérie (Actinotrichida, Tetranychoidea: Tetranychidae, Linotetranidae) - Ann. de l' Ecole Nat. d'Agric. d'Alger, 3(3): 1-10.

Bagheri M., Haddad Irani-nejad K., Kamali K., Khanjani M., Saboori A., Lotfollahi P. 2008 - A new species of Linotetranus (Acari: Prostigmata: Linotetranidae) from Iran - Zootaxa, 1914: 65-68.

Baker E.W., Pritchard A.E. 1953 - The family category of tetranychoid mites, with review of the new families Linotetranidae and Tuckerellidae - Ann. Entomol. Soc. Amer., 46(2): 243-258.
Beard J.J., Walter D.E. 2004 - Cryptic false spider mites: a new genus, Austrolinus and a review of the family Linotetranidae (Acari: Prostigmata: Tetranychoidea) — Invert. Syst., 18: 593-606. doi:10.1071/IS02049

Berlese A. 1910 - Acari nuovi-Manipulus V. Redia, 6: 199-234.

Doğan S., Dönel G., Bal D. A., Sezek F. 2010 - The first occurrence of the mite family Linotetranidae (Acari: Tetranychoidea) in Turkey: Linotetranus anatolicus n. sp. - Internat. J. Acarol., 36(1): 27-34. doi:10.1080/01647950903496571

Khanjani M., Asali fayaz B., Khanjani M. 2011 - Two new species of Linotetranus (Parasitiformes: Tetranychoidae: Linotetranydae) from Iran - Zootaxa, 2834: 47-56.

Krantz G.W., Walter D. 2009 - A Manual of Acarology $3^{\text {rd }}$ ed. - Texas Tech University Museum Special Publication, Lubbock, TX, USA. 807 pp.

Lindquist E.E. 1985 - Anatomy, phylogeny and systematics - 1.1.1. External anatomy. In: Helle, W., Sabelis M.W., (eds.), World Crop Pest, Vol. 1A. Spider mites, their biology, natural enemies and control. Amesterdam, Elsevier, p. 3-28.

Meyer (Smith) M.K.P., Ueckermann E.A. 1997 - A review of the some species of the families Allochaetophoridae, Linotetranidae and Tuckerellidae (Acari: Tetranychoidea) - Internat. J. Acarol., 23(2): 67-92. doi:10.1080/01647959708683103

\section{COPYRIGHT}

$(\mathrm{cc})$ EY-No-ND Khanjani M. et al. Acarologia is under free license. This open-access article is distributed under the terms of the Creative Commons-BY-NC-ND which permits unrestricted non-commercial use, distribution, and reproduction in any medium, provided the original author and source are credited. 